\title{
A Estrada do Pacífico: Necessidade e Custos Sócio-Ambientais*
}

\author{
Mauro Leonel, Luiz Sanná Pinto, \\ Julieth Aquino, Janine Salles de Carvalho**
}

Resumo: As estradas chegaram a ser a medida de boas políticas públicas: "governar é construir estradas", já foi dito no Brasil, pré e pós JK. No entanto, na história das civilizações, as estradas nunca deixaram de ser penosas para os conquistados. $O$ caso da Estrada do Pacífico compromete ecossistemas frágeis das diversidades amazônicas, desrespeita as populações tradicionais, povos tribais e populações Quechuas e Aymaras das encostas andinas. A estrada do Pacífico é apenas um dos trechos dos planos de infra-estrutura que também se dirigem, via Guianas, ao Caribe. A pergunta é: como ficam florestas, povos e encostas andinas?

Palavras-chave: Estrada do Pacífico, Custos Sócio-Ambientais, Amazônia, Integração LatinoAmericana, Custos Sócio-Ambientais.

Abstract: Roadswere, in some extent, is the measure of good public policy: "govern is to build roads," as already has been said in Brazil, pre and post JK. However, in the history of civilizations, the roads were also a source of troubles for the conquered. The case of the Pacific Road threats fragile ecosystems of the Amazon's diversities disrespects the traditional populations, tribal people and Quechuas and Aymaras populations of the Andean hillsides. The Pacific Road is only one of the stretches of the infrastructure plans that are also intended for the Caribbean, through the Guyanas. The question is: and what about people and Andean hillsides?

Keywords: Pacific Road, Socio-Environmental Costs, Amazone, Latin American Integration, SocioEnvironmental Costs.

\footnotetext{
* Esse artigo retoma indicações de estudo anterior publicados em inglês e espanhol, em 1992, pela IWGIA em Copenhagen.

** Mauro Leonel: Professor Doutor da Escola de Artes, Ciências e Humanidades - EACH/USP Leste, do Programa de PósGraduação em Integração da América Latina - PROLAM/USP e da Pós-Graduação em Ciências Sociais da UNESP/FFC, do IAMÁ e do PPSE. E-mail: mauromli@terra.com.br. Luis Sanná Pinto: Mestrando do PROLAM/USP, pesquisador do Instituto de Antropologia e Meio Ambiente (IAMÁ) e do PPSE. E-mail: luizpinto8@gmail.com. Julieth Aquino: Monitora de Projetos de Pesquisa do IAMÁ e pesquisadora do Grupo de Pesquisas sobre Processos Políticos Sociais e Exclusão. E-mail: maurojuliet@yahoo.com.br. Janine Salles de Carvalho: Mestranda do PROLAM/USP, pesquisadora do IAMÁ e do PPSE. E-mail: janis_salles@yahoo.com.br. Recebido em 29/05/08 e aceito em 15/06/08
} 


\section{Endocolonialismo}

Sem dúvida há grandes interesses determinando políticas públicas aos países dependentes, a partir do hemisfério norte. Mas a intrincada espiral desses interesses, que determina o desacerto das grandes obras de impacto, começa, freqüentemente, em pequenos grupos regionais e nacionais. No caso brasileiro, tome- se o exemplo das grandes construtoras, ingovernáveis, simplesmente por serem ilegitimamente governo, nos corredores dos palácios e no controle da mídia.

Mas é fácil e cômodo atribuir tão freqüentes desastres apenas ao poder de fazer obras inadequadamente, e em interesse próprio, das grandes empreiteiras, algumas reconhecidas internacionalmente por sua capacidade de bem construir. Onde há uma estrada, há uma mineração, uma madeireira, agropecuária, comércio, banco ou financeira, e tudo conduzido por uma elite político-militar comprometida, cavando sua vez de promover acumulaçáo rápida e predatória, e exportar. Trata-se de uma intrincada malha de interesses articulados, cujo centro é a elite nacional, que escapa ao controle social, tendo na ponta um colono sem terra e destino, peão ou garimpeiro, sem raízes ou horizonte. Todo reducionismo na explicação tende a enfraquecer a eficácia da boa intençáo dos que pretendem mudanças.

As grandes obras foram apanágio dos regimes autoritários. Estes são, de fato, excelente caldo de cultura para os "fazedores de hecatombes", como disso Euclides da Cunha. A abertura democrática no Brasil mostra, no entanto, que muita coisa continua como dantes, e com rostos e atitudes outrora conhecidos. $\mathrm{O}$ advento formal da democracia não assegura, milagrosamente, a eliminação dos mecanismos subterrâneos, que determinam os gastos públicos a orientar-se por interesses privados.

Onde está, entâo, o promotor da grande obra pública desastrosa na Amazônia contemporânea? Deve ser buscado no modelo exportador para o "desenvolvimento", que necessita abrir, constantemente, fronteiras novas à acumulação econômica. $\mathrm{Na}$ extemporânea mentalidade endocolonial, que cobiça dispor das amazônias a serviço das minorias do sudeste brasileiro, em três sentidos: consumí-las, exportá-las e desfazer-se dos sem-terra e outros marginalizados, forçando-os à migração, prometendo-lhes a aventura e, quiçá, uma amarga e fugaz fortuna garimpeira, que lhes escorrerá entre os dedos, ou solos frágeis, donde mal retira uma colheita. 
Enfim, está contida num modo de vida universalizante, no modelo caricato do Primeiro Mundo, que impóe tecnologias, cria mercados, colonialismo interno, dependência energética, arrasando, em sua passagem, a diversidade da condição humana e a natureza que a permite.

De pouco vale clamar por uma milagrosa intervenção do paternalismo e do sentimento de culpa da solidariedade internacional. A pressáo externa tem sido importante, mas sua eficácia mostrou sempre claros limites. Deve ser convocada a apoiar o fortalecimento da auto-representação direta das populaçóes, apoiadas por instituiçóes locais autônomas, por pesquisa rigorosa e independente. Mas há que evitar, no entanto, a ilusão do populismo e do fortalecimento ingênuo do acaudilhamento, ou de pseudolideranças, fenômenos de mídia, para consumo urbano e externo, mais um exorcismo da culpa do que eficácia na qualidade da representação.

Uma sociedade democrática não se constrói pela centralização autoritária, mesmo quando discursivamente bem intencionada ou opositora. Para a realização da democracia é indispensável a diversidade de opinióes, pelo seu efeito multiplicador e corretivo. Nas políticas públicas, sobretudo, é fundamental qualificar as contra-propostas, ou seja, estimular instituiçóes independentes de pesquisa alternativa que ofereçam suporte, instrumentos analítico-críticos às reivindicaçóes organizadas das populaçóes autorepresentadas.

Para reorientar a pesada herança importada do "progresso" e "desenvolvimento", é preciso priorizar a qualidade de vida das populaçóes, em particular das milenarmente pioneiras. Os amazônidas e os andinos deverão estar no centro do planejamento. Garantir a sustentabilidade, a renovabilidade de seus recursos naturais, a adequação de seus modos de uso à integração no mercado, retomando o sábio caminho da auto-suficiência, substituindo dependência por inter-relação duradoura, por novos patamares de valor de troca, onde se contabilize escassez e diversidade de recursos. Também será inócuo tentar compreender o impacto dessas grandes obras, isolando a questão indígena ou ambiental, da dinâmica de dominaçáo endocolonial. 


\section{Os conceitos de impacto, zoneamento, interdisciplinariedade}

Esse é o primeiro desafio metodológico, a revisão do conceito de impacto das estradas. Ultimamente, com as críticas feitas à sem-cerimônia com que se construíram estradas nas duas últimas décadas na Amazônia, o governo brasileiro vem admitindo estudos prévios de impacto, mas para "inglês ver", segundo uma expressão popular no Brasil. Ou seja, não são para ser aplicados, mas para responder aos críticos.

A equipe responsável pelos planos rodoviários chegou a nomear um engenheiro para cuidar da questão ambiental. Isolado, mesmo que competente, nada poderia mudar. No governo brasileiro, trabalha-se nas grandes construtoras e consultoras interligadas, quase sempre, pelo menos na maioria dos casos estudados, com uma definição apenas quantitativa e, portanto, arbitrária, das implicações de obras de porte sobre as populaçóes atingidas e sobre os recursos naturais, expostos pela via de penetração à exploração massiva. Propõe-se aqui uma revisão dessa prática metodológica, que se vem mostrando inadequada, com graves conseqüências às populaçóes e ao meio ambiente.

Com freqüência, dividiam-se partidários de uma área de abrangência de impacto maior ou menor, variando de vinte a cem quilômetros em linha reta, no entorno da estrada. A região nunca foi considerada como um conjunto, mas como margem da estrada, em sua pré-versão cartográfica. No entanto, a questão qualitativa não está na distância vista da prancheta de engenharia, mas no ecossistema e na realidade socioeconômica da população atingida, considerada em seu conjunto. Mas os técnicos, geralmente competentes construtores, pretendem limitar as medidas preventivas a distâncias obtidas por linhas retas nos planos cartográficos.

Não compreendem que as populaçôes, a diversidade cultural, os ecossistemas, as bacias, deveriam determinar adequadamente a cartografia rodoviária, e não as estradas se imporem às realidades, como vem ocorrendo. Os patrôes que encomendam estudos de impacto têm pressa, e um controle de tipo cartorial não os intimida, ou seja, os estudos não modificam traçados, mas dão satisfação burocrática às exigências legais.

Uma estrada, assim como outras grandes obras, é um pólo de atração inevitável, redundando em escoadouro de todas as atividades de uma região. 
Rapidamente torna-se o tronco principal de numerosas estradas secundárias, intermunicipais, de serviço, picadóes, varadouros e ramais. Enfim tudo se fará para alcançá-la, tornando-a um centro de escoamento, atraindo inclusive o transporte fluvial na beira dos rios que permitam acesso à nova estrada.

Assim, não é uma estrada que se deveria considerar isoladamente, em termos de política pública, mas o conjunto de uma malha viária, tanto a regular quanto a irregular, estimulada pela iniciativa privada, em particular madeireiras, agropecuárias e mineradoras e grãos É um plano viário, não obsessivamente rodoviário, mas de um complexo de comunicações e transportes que deveria ser pré-analisado no contexto de suas implicaçóes sócio-econômicas e ambientais.

Tal plano viário não necessita privilegiar o transporte rodoviário. Deveria partir das necessidades da população local para seu planejamento. Necessidades sugeridas pelo mercado internacional podem adaptar-se a esse plano, mas não impor-se à realidade regional, fazendo com que gire ao redor da obra. Ao contrário, desenvolvimento deveria ser pensado primeiro para dentro, na região, como auto-suficiência, antes de articular-se para fora.

O impacto de uma obra apenas poderá ser medido peio conjunto das alterações que provocará e das ligaçóes de toda ordem que promove, considerando o conjunto da região que passará a centralizar, como principal via de comunicação e meio de transporte. Seu fundamento deveria ser a busca da qualidade de vida da população regional.

\section{Uma estrada nunca é obra isolada}

Segue-se, a uma estrada, um conjunto de outras obras ou atividades produtivas de grande alcance. Uma das mais evidentes é as de ordem energética, como as grandes hidroelétricas somadas às mineraçóes, madeireiras, agropecuárias e outras. Um plano viário adequado deve partir de um estudo detalhado dos graves problemas energéticos a serem introduzidos pelo estilo desenvolvimentista que se quer promover na regiáo. Tal estudo deve considerar inclusive hipóteses menos convencionais, combinadas e alternativas, como a biomassa, hidroelétricas de pequeno porte a fio d'água solar, dentre outras disponíveis na própria região.

Outro elemento inevitável é a mineração. Não houve como, nesta 
pesquisa, levantar as incidências minerais nos exemplos citados. Mas seu aprofundamento indispensável para se conhecer o impacto inevitável sobre populaçóes e ambiente, como o garimpo, trazendo o mercúrio além dos resíduos e estragos da extração da cassiterita e da bauxita, dentre outros minérios, condenando os rios da Amazônia, alguns para sempre.

A questão chave está na ótica conceitual que orienta os projetos-padrão de desenvolvimento regional. Os demais componentes são tratados como complementos à obra-estrada, quando freqüentemente deveria ser o inverso. Um planejamento sócio-ambiental que oriente o desenvolvimento das regióes em pauta não pode estar condicionado pela eventualidade de uma grande obra, deve precedê-la conceitualmente, e em seu cronograma. A mesma observação vale para os projetos de assentamento e agropecuárias, geralmente previstos de forma precipitada e inoportuna.

As graves distorções criadas por projetos desse tipo - os PDR I-Projetos de Desenvolvimento Rural Integrados camuflando estradas, estiveram na moda na última década e em particular na década de oitenta, não se aconselha a tentativa de repetí-los. Apesar de alguns desses projetos conterem salvaguardas, quanto à proteção aos índios e ao meio ambiente, mais recentemente até aos seringueiros, não resolvem o problema, são acrescentados como adornos e não contêm as experiências anteriores como medidas preventivas.

É possível considerar-se algumas estradas como necessárias vias de comunicação, e apropriadas, mas o procedimento proposto é inadequado. $\mathrm{O}$ mesmo vale para os projetos de assentamento, para as medidas de proteção aos indígenas ou ambientais, impropriamente formuladas, parecendo apenas embalagens melhoradas para a viabilização da obra central, estrada ou hidroelétrica, como se viu em passado recente.

Alguns altos funcionários do governo brasileiro têm solicitado a pesquisadores pareceres, assessorias ou avaliaçóes, mas não toleram que se ponha em causa os fundamentos de um determinado projeto. Pretendem, em curto espaço de tempo, uma manifestação que, em nenhum caso, poderia ser feita de forma ligeira. Todas as situaçóes precedentes, como das ferrovias de Carajás e Norte-Sul, ou no caso de estradas, como a BR-364, BR-429 ou a estrada do Pacífico, necessitariam longos estudos interdisciplinares. As experiências anteriores obrigam a rever conceitos fundamentais com maior 
responsabilidade, do que apenas alterar, contribuir, completar ou corroborar aspectos secundários, ou até mesmo itens importantes de um determinado projeto.

Aqui se propóe uma revisão conceitual de grande abrangência, a elaboraçáo de uma nova sistemática para projetos, cujo centro orientador seria o uso adequado dos recursos naturais, a partir da população que atualmente está ocupando essas regióes. Tal sistemática deverá ser antecedida por uma cartografia e zoneamento ambiental, e apenas após sua execução tornar-se-ia viável considerar assentamentos ou grandes obras, ouvidas as populações diretamente envolvidas. Sua conclusão deveria culminar, numa contribuição interdisciplinar concreta para o delineamento dessa nova sistemática, que introduzisse adequadamente a inter-relação entre as questôes sociais e ambientais envolvidas nos grandes projetos na Amazônia. Em particular, as relativas às saídas econômicas sustentáveis e alternativas energéticas adequadas.

\section{Transporte integrado e intermodal}

A Amazônia, apenas em sua parte brasileira, conta com vinte e cinco mil quilômetros de rios navegáveis. As primeiras levas de migração, movidas pelo ciclo extrativista da borracha, madeira e minérios, criaram redes de transporte fluvial mais ou menos informais, conforme as solicitaçóes do mercado. As estradas de rodagem na Amazônia não consideraram alternativas, nem as realidades e especificidades regionais, nem mesmo para uma articulação entre diferentes modalidades.

$\mathrm{Na}$ verdade, essa versão caricata do desenvolvimento à americana, em quatro rodas individualizadas, é a representação de um original adulterado. A economia considerada desenvolvida vem sendo obrigada a dar franca preferência, no sentido de base, ao transporte ferroviário como modalidade principal. Regiōes inteiras foram desenvolvidas também a partir do transporte fluvial, como é o caso do Mississipi Valley. Mesmo quando outras modalidades foram se impondo, o modo fluvial não foi desmontado, como no Reno e em vários dos países europeus. A articulação entre o ferroviário, rodoviário e fluvial, é muito freqüente em outros países. Por exemplo: até hoje não há uma rodovia dupla entre Berna e Genebra, simplesmente porque 
os cidadãos votam democraticamente contra.

Tal distorção rodoviária brasileira, freqüente no hemisfério sul, terminou criando custosas dependências energéticas e tecnológicas, além de elevados custos de manutenção e dependência externa. Anteriormente não se considerava o impacto sobre as populaçóes e o ambiente, delegava-se aos técnico-especialistas em compartimentos estanques, geralmente engenheiros, a competência global de construir. As exigências contemporâneas, no entanto, obrigam a um tratamento multidisciplinar, onde o campo das competências deixa de ser uni manto protetor do obscurantismo.

Nessa ótica, são indispensáveis respostas inequívocas ao porquê da opção por uma determinada modalidade de transporte, e sobre as possibilidades de articulação de diferentes opçóes. Até mesmo porque o impacto sobre ecossistemas e populaçóes é diferenciado, em conformidade com o meio de transporte a ser adotado e o tipo de articulação e solução intermodal que se possa alcançar, a partir da qualidade de vida das populações envolvidas, única base ética possível à política pública.

Há que ser analisado, em mais detalhes, o peso das empreiteiras construtoras, que terminam por financiar o próprio governo, tornando-o devedor delas. São as maiores interessadas em privilegiar a opção rodoviária. A construtora Mendes Júnior, por exemplo, uma das interessadas na BR429 e na estrada do Pacífico, "tem algo em torno de 360 milhóes de dólares para receber do governo por obras realizadas, e esse dinheiro está demorando a sair" (Veja, 13/5/1987). Apesar disso, a empresa apresentava um lucro, em 1986, de 521 milhóes de cruzados e tinha 35 mil empregados. Foi a responsável pelo maior trecho da Transamazônica.

Já não se sabe se as empreiteiras existem para realizar as obras, ou se as obras para engordar as empreiteiras. "A Associação Brasileira de Engenharia Industrial tem 120 associados: algumas construtoras como a Camargo Correia, Mendes Júnior, Tenege, Norberto Odebrechet, Andrade Gutierrez e Montreal, juntas, faturaram 5 bilhóes de dólares em 1987...”, informou o presidente da entidade, Fernando Couto Marques Lisboa, acrescentando que o governo deve às empresas de construção 75 bilhóes de cruzados (OESP, $11 / 3 / 1988)$. 


\section{Interdisciplinariedade e debate público}

Nem sempre no passado levou-se em conta, de maneira adequada, o tratamento multi e interdisciplinar no planejamento público de grandes obras de impacto. Freqüentemente recorria-se a profissionais de diferentes áreas nas grandes consultoras de planejamento, convidados, no entanto, muito mais para fundamentar uma opção previamente traçada, que para estimular o rigor com que devem ser tratadas as políticas públicas.

O recurso aos especialistas, assegurada a liberdade crítica para que desenvolvam a interação de conhecimentos, é indispensável. Mas é importante ainda que se promova um debate amplo com a comunidade científica, em particular a dos países envolvidos e fronteiriços.

Tal defasagem poderá ser resolvida por um estímulo ao intercâmbio multilateral regional, envolvendo todos os países amazônicos, como suporte ao recente esforço diplomático desenvolvido na mesma direção. Chegou-se ao paradoxo de que a Amazônia conta com maior pesquisa e pesquisadores norte-americanos e europeus que os países diretamente interessados. No entanto, tais pesquisas não se orientaram para una visão integradora, permitindo respostas concretas aos problemas emergentes da região: geraram conhecimentos, muitas vezes úteis, mas estanques, e posiçóes principistas, em descompasso com a realidade. Tal carência de pesquisa é ainda mais flagrante nas áreas das ciências sociais e ambientais. Em particular, antropólogos e sociólogos são considerados desnecessários e chatos, são chamados apenas para que assinem pareceres, como num cartório de quarteirão.

É importante realizar encontros com a comunidade científica, troca de informaçóes e opiniôes com especialistas de diversas áreas e com as organizaçóes não-governamentais. Sobretudo, com as organizaçóes representativas das populaçóes, em particular as da região amazônica. Os índios, as comunidades ribeirinhas, os seringueiros, devem ser, por suas organizaçóes locais na regiáo a ser atingida, os primeiros a serem ouvidos.

Acumulou-se uma concepção hermética no planejamento público, cristalizado na idéia de que quanto mais seletos e restritos os envolvidos, melhor seria o resultado. Dessa prática do segredo, de uma visão excessivamente tecnocrática no planejamento, é que se provocaram numerosas distorçóes nas políticas públicas. Em projetos bi ou trinacionais de amplo alcance, 
como os que vêm sendo discutidos no pacto amazônico, será necessária a abertura de um debate público de alto nível, aprofundando-se os mecanismos democráticos de decisão, que se encontram em curso de consolidação e legitimação no Brasil e em países vizinhos.

\section{Prévio zoneamento sócio-ambiental}

Novos projetos de estradas de grande porte, como os que vêm sendo propostos, devem ser precedidos por rigorosos zoneamentos prévios. Como método, seria recomendável pré-cenários das implicações possíveis da passagem da estrada pelas regióes previstas, com vistas às medidas preventivas quanto ao uso adequado dos recursos naturais e às populaçóes hoje existentes. Tais estudos devem implicar, inclusive, a inclusão dos critérios de redefiniçâo do próprio traçado, que não deverá ser decidido apenas a partir da engenharia de construção, e sim interdisciplinarmente.

Um bom exemplo para fundamentar essa recomendação é o caso da Estrada de Ferro Carajás. Após sua construção, reanalisando as conseqüências daquele traçado, técnicos da mineradora estatal Vale do Rio Doce, responsável pelo projeto, chegaram à conclusão de que teria sido mais eficaz evitar a área dos índios Gavião do Pará. Teriam acrescentado alguns quilômetros a mais para o desvio, mas contornado pesados conflitos. Prevenir é melhor que remediar, e se teria evitado pesados ônus aos índios, ao governo e à própria empresa. Medidas prévias poderiam ter evitado ou moderado a devastação provocada pela ferrovia.

Este tipo de tentativa, de prévio zoneamento, também tende ao fracasso, caso não venha a integrar a comunidade científica brasileira e sul-americana, e contar com uma orientação de fora para dentro, a partir do hemisfério norte. Um zoneamento adequado deve partir da especificidade da situação socioeconômica de cada país, levar em conta a ocupação atual, os graves problemas postos pelo avanço da fronteira econômica e o uso adequado dos recursos naturais disponíveis, sua renovabilidade e as populaçóes tradicionais amazônicas.

Uma iniciativa como essa exige forte vontade política, mas poderia criar o consenso social indispensável em torno de única orientação para o uso adequado do espaço amazônico. Não se trata, assim, de proceder a um 
zoneamento para responder às necessidades de uma obra específica (estrada, hidroelétrica, ou mineração), colonização, agropecuária ou exploração florestal. Não é o espaço que se compatibilizará com a obra, mas esta que se adequará às variáveis sócio-ambientais possíveis de antecipação. Faltou esta visão, por exemplo, no caso das tentativas de promover o desenvolvimento regional a partir de uma hidroelétrica ou de uma estrada, embora seja positivo que conceitos ambientais tenham sido introduzidos, incipientemente, na Eletronorte, no DNPM e no DNER.

\section{Zoneamento por células e por bacias}

Tal zoneamento deve partir de uma cartografia básica por células regionalizadas, como recomendado pelo mestre emérito Ab'Saber (1989), contendo a "rede hidrográfica e os delineamentos mais expressivos dos compartimentos topográficos”, necessitando das especificaçóes climática, geológica, distribuição dos solos e vegetação; evoluindo ainda para os sistemas de comunicação, núcleos urbanos, áreas indígenas e de preservação: mineração, obras planejadas; padróes de florestas: indo em direção a ocupação e uso atual, dominando todas as variáveis, tanto a sócio-econômica quanto a diversidade cultural e a biodiversidade.

Trata-se de pesquisa básica que exige atualização bibliográfica e pesquisa de campo, tornando-se um instrumento básico e permanente de planejamento sócio-econômico-ambiental. A eventualidade de grandes obras deve apressar a urgência desses estudos básicos, tanto aplicadamente a uma região, como preventivamente à Amazônia como um todo. É lamentável que os zoneamentos pensados até agora considerem apenas uso agrícola no estilo plantaçóes ou pastagens, e não as populaçóes e o uso adequado, como na presente proposta.

\section{Conceito de bacia}

É indispensável a introdução do conceito de bacia no planejamento sócioambiental aqui proposto. Não é mais a estrada o centro do planejamento, mas sim o uso renovável e sustentável dos recursos naturais, e o primeiro deles é a água, os recursos hídricos. A legislação brasileira é clara ao proteger nascentes e margens de rios no Código Florestal. Os projetos de estradas é 
que serão considerados a partir do conjunto da bacia, dentre outros fatores, e não o inverso.

O professor Aziz Ab’Saber (1988), advertiu em uma palestra que, em cerca de $80 \%$ do espaço amazônico, "qualquer devastação em faixa contínua, ao longo dos divisores secundários, acarreta uma desperenização das drenagens de cabeceiras de igarapés. E, à medida que se ampliam as derrubadas, a partir dos interflúvios, amplia-se também o setor de desperenização no alto vale de minguados igarapés". Lembrou ainda que a frente de devastação preferencial parte dos grandes eixos viários, ou de "importantes setores interfluviais, onde foram locadas rodovias federais ou estaduais, responsáveis pela abertura de sucessivas agropecuárias, dotadas de frágeis pastagens em cabeceiras de igarapés, atualmente desperenizados...”. Referiu-se ainda, ao "apossamento legal ou ilegal ao longo de rodovias, estradas de serviço e ferrovias”.

Outras, dentre as razóes importantes para que se considere o conjunto da bacia, são: garantir o uso múltiplo dos rios, a navegabilidade, a pesca, o abastecimento dos núcleos urbanos, uso energético, turístico, agricultura, dentre outros.

\section{A implementação do zoneamento é anterior às obras}

O zoneamento sócio-ambiental que se faz necessário para a Amazônia como um conjunto não se resume a uma cartografia ambiental. Esta é apenas um instrumento de trabalho preliminar, uma base de dados indicativos das medidas a serem tomadas, e previamente ao início de grandes obras. Tal inversão corretiva foi proposta pela avaliação do Polonoroeste, no caso do PMACI I e II, após as amargas experiências de Rondônia e norte do Mato Grosso. Resolveram o governo e o BID, no entanto, permitir que o asfaltamento da estrada BR-364, trecho Porto Velho - Rio Branco a caminho do Pacifico ate Porto Illo, fosse iniciado antes mesmo da definição de medidas preventivas. No primeiro ano do início do asfaltamento, em 1992 no trecho Porto Velho - Rio Branco previa-se a demarcação de nove áreas indígenas. Apenas uma delas foi efetivamente demarcada na altura, pelo PMACI I, financiado pelo BID e até hoje, cinco anos depois, nenhuma área está totalmente regularizada.

Não apenas se restringiu a área de abrangência a cinqüenta quilômetros 
da estrada, como liberou-se o cronograma do asfaltamento sem nenhuma compatibilização com as medidas sócio-ambientais. O mesmo ocorreu com as reservas extrativistas dos seringueiros. De cerca de cinqüenta consideradas para o Estado do Acre, apenas três estavam sendo implantadas, mas ainda não resolvidas. Em Rondônia, das 35 áreas levantadas pelo IAMÁ, apenas uma conta com medidas de regularização fundiária. E sabe-se que 16 anos depois que nenhuma dessas áreas estão totalmente asseguradas.

No futuro há possibilidades de se proceder de maneira diferente, aprendendo das experiências anteriores. Para que tal ocorra, é indispensável que o cronograma das medidas preventivas sócio-ambientais condicione o início de qualquer obra, ou seja, que tais medidas antecedam claramente a obra, sem tergiversaçóes. Pseudocompatibilizaçóes de calendários visam na verdade camuflar a obra, pontuando em plano secundário o uso adequado dos recursos naturais, e o direito das minorias, que deveriam orientar primariamente as políticas públicas na Amazônia. Além de condicionarem o início das obras, as medidas preventivas e corretivas devem continuar condicionando suas diferentes etapas, ou as tarefas sociais e ambientais, geralmente postas em segundo plano pela tecnoburocracia, não serão executadas. A obra estará pronta e as medidas preventivas tornam-se corretivas, ou até inúteis.

Há que se prever o prazo para que tais medidas preventivas sejam planejadas e tomadas. Tal previsão, no entanto, deve condicionar o início da obra, ou seja, quando o asfaltamento se inicia, as áreas indígenas, extrativistas, reservas florestais, uso renovável dos recursos naturais, participação das comunidades, já se encontrarão implementadas. Apenas condicionando estreitamente os cronogramas, poder-se-á evitar a repetição de antecedentes, como os do caso brasileiro. Polonoroeste e PMACI.

\section{Clarificação dos interesses Peru-Brasil-China-Japão}

Trata-se de uma única questão chave, bastante mal esclarecida nas discussóes sobre a estrada. O tipo de demanda desse intercâmbio determina conseqüências na ocupação do espaço diferenciadas, riscos de especialização para o mercado que devem ser aprofundados. Fala-se muito na exportaçáo de grãos ao Oriente, ao Japão em particular. A estrada significaria um lucro de 100 dólares por tonelada de grãos, com a economia de 9 mil quilômetros 
na rota brasileira ao oriente. $\mathrm{O}$ cerrado brasileiro teria grande capacidade de produzir excedente (FSP,28110/1990:A-18 e Globo Rural, 10/90). Mas quais as conseqüências dessa expansão de monoculturas de exportação sobre a qualidade de vida da população brasileira? Quais os seus limites?

Evitam-se, no entanto, referências às necessidades japonesas, chinesas, e de todo o Extremo Oriente em madeira; com a devastação em curso, estão condenadas as últimas reservas de florestas tropicais da região. As medidas preventivas não são discutidas em profundidade. Ao contrário, os defensores da viabilização imediata da estrada, zangados, acusam os ambientalistas de defenderem as exportaçóes norte-americanas de grãos, em prejuízo das potencialidades brasileiras no mercado.

Mas será que os brasileiros ganharão efetivamente com estes previstos 400 caminhóes diários de soja em direção ao Oriente? Qual o impacto ao destinarem-se milhóes de hectares à exportação e à concentração fundiária em um país como o Brasil, onde a maioria da população é mais pobre do que a da Colômbia e do Paraguai? O que ganham as populaçóes locais? Quais as garantias de renovabilidade dos recursos, em particular da madeira, cobiçado potencial amazônico?

Perguntado sobre o impacto da integração viária com o Brasil, José del Maestro, presidente da Frente de Defesa de Madre de Dios, respondeu à revista Sur, de Cuzco: "Este projeto pode chegar a realizar-se, mas em igualdade de condiçóes. Não podemos, por uma estrada, asfaltada ou não, hipotecar nossos recursos naturais. Todos sabemos as intençóes que tem o Brasil. Somos vizinhos a um país irmão, a Bolívia, com quem podemos compartilhar quase a mesma estrutura econômica. Mas não com o Brasil, que é um país hegemônico".

Para um trato eqüitativo, o entrevistado propunha um plano de industrialização e de aproveitamento dos recursos naturais, além da autonomia regional para Madre de Dios, e acrescentou: "O problema é que somos consumidores do que o Brasil produz, mas o Brasil não consome nada do que temos. Nós sustentamos que esta grande contradição deve ser superada, através de uma ação preferencial do Estado peruano sobre os problemas de Madre de Dios."

Essa preocupação é bastante disseminada na opinião regional. É muito 
importante que se lhe dêem respostas claras, ou seja, que venham a ser previamente estudadas as conseqüências, no intercâmbio entre os dois países, da abertura de um eixo viário de importância. Algumas indicaçóes foram feitas, mas ainda insuficientes como previsão. É seguro que Brasil e Peru poderão sair ganhadores de uma parceria de maior entrosamento, mas dificilmente ganharão se for improvisada.

As poucas respostas enunciadas referem-se a que o Peru poderia exportar ao Brasil produtos minerais, sobretudo fertilizantes, e gás. Há que se dimensionar essas alternativas. Assim como as conseqüências para o Brasil e o Peru da ampliação de possibilidades de acesso aos mercados do Oriente e da costa oeste da América do Norte.

Há também obstáculos financeiros. Brasil e Peru vivem delicada situação econômica, com importantes dívidas internacionais. O Japão não tem condições de financiar um empreendimento desse porte, por razões diplomáticas, sem a solidariedade da Europa e dos Estados Unidos. Para isso, necessita de garantias de proteção ao ambiente e às populaçóes locais, conforme as convençóes internacionais e as normas, cada vez mais restritas, da CEE, BM, BID e de outras agências financiadoras multilaterais, e mesmo bilaterais. Uma repetição dos acontecimentos de Rondônia criaria grave oposição da opiniāo internacional, como criaria na década de 80-90 com o BID no Acre, e com o BM no Polonoroeste.

Por outro lado, como foi dito na abertura, por que rodovia? Qual a interação com as demais possibilidades de transporte em uso na regiáo? Qual o papel das populaçóes tradicionais e dos recursos naturais em tais planos?

\section{Os índios do noroeste da Bolívia e a estrada}

Um dos caminhos mais ágeis para a ligação Brasil-Peru-Pacífico é, sem dúvida, a Bolívia. Considera-se, no entanto, que as negociações bilaterais são já em si difíceis, e que as trilaterais trariam enormes dificuldades. O argumento é razoável, mas não é excludente. Para a geopolítica dessa região, é importante que se mantenham, no quadro dessa triangularidade, contatos multilaterais de várias ordens. Há necessidade de contatos, ao menos bilaterais, entre o Brasil e a Bolívia, entre o Peru e a Bolívia, já iniciados com o apoio do BID, e nas negociaçóes do Pacto Amazônico. 
Uma estrada entrando por Assis Brasil e Inapari, em direção a Puerto Maldonado e Puerto Illo, ladeia as fronteiras Brasil-Bolívia, e Peru-Bolívia, em uma linha paralela de dezenas de quilômetros. Mesmo no estado precário para a estação seca em que se encontra a atual estrada que atravessa Madre de Dios, já há seis saídas com pontes entre o Peru e a Bolívia. Esses dois países já estudaram sua integração nesta região em passado recente. Do lado boliviano existe também uma estrada, até o sul do país, embora precária, que ladeia a fronteira.

De qualquer forma, um eixo viário de grande importância não deixará de atrair todas as atividades regionais, por via fluvial, por ramificaçóes improvisadas de madeireiras, mineradoras ou agropecuárias, ou iniciativas municipais bolivianas. Assim, torna-se imperioso considerar o noroeste boliviano como área de impacto da estrada.

Uma solução, já aventada, é a poligonação do noroeste boliviano com o Brasil (por Basiléia, Cobija), e com o Peru, (desta mesma cidade a Iberia ou Puerto Maldonado). Esta solução traria a vantagem de permitir a integração dos três países, mesmo que em negociações bi ou trilaterais múltiplas. Ela impóe o zoneamento ambiental do noroeste boliviano, feito pelo governo deste país, em articulação com os vizinhos, atenuando a tensão nas vizinhanças.

É inevitável que a estrada asfaltada traga conseqüências ao país vizinho. $\mathrm{O}$ centro desse impacto é novamente relativo à valorização das terras, às questôes ambientais, ao uso dos recursos naturais e às comunidades indígenas de floresta e às populaçóes locais ou ribeirinhas.

Essa realidade obriga ao planejamento detalhado, mesmo que a principal das negociaçóes dê-se ao nível da bilateralidade. Novamente impóe-se a obrigação de planejar pelo conjunto das bacias envolvidas. No caso brasileiro, a iniciativa de uma negociação e cooperação bilateral impóe-se também com vistas a criar um novo clima na regiâo, onde há uma tensão que remonta há décadas, não havendo vantagens em prolongá-la, dada a estabilidade das fronteiras.

A iniciativa Bolívia-Peru, em curso, é altamente positiva para essa integração, através do Programa de Apoio à Integração Fronteiriça BolíviaPeru, Projeto de Exploração Integral da Borracha - BID. A colaboração 
concreta, pelo uso adequado dos recursos naturais, ao menos conceitualmente, está mais adiantada entre a Bolívia e o Peru, que no caso da colaboração Acre-Madre de Dios. Tal fato deve-se a um pequeno empréstimo do BID para o feito, de quinhentos mil dólares. No inicio da década de 90, a grande lacuna do projeto, a verificar, uma vez que não se chegou a entrevistar seus planificadores ou executores, é a ausência de previsão para o estabelecimento de reservas extrativistas, com a finalidade de garantir, a longo prazo, o uso adequado. Há referências a garantir, cerca de 100 hectares por família, mas não se diz como; e estradas de seringa não se preservam como lotes de colonos.

O projeto citado pretendia em 1990 atingir, do lado peruano, cerca de mil seringueiros, na região de Tahuamanu, lberia, Inapari, San Lorenzo e Alerta. Propunha-se passar da produção à transformação primária do produto, semi industrializando-o na região, através de um entrosamento maior entre profissionais extensionistas e produtores, criando-se empresas binacionais. $\mathrm{O}$ projeto parece ter enfrentado problemas de execução por dificuldades institucionais.

O povo indígena Ese'eja foi o melhor exemplo das ligações e repercussóes que virão da integração viária Brasil-Peru sobre as populações do noroeste boliviano, porque vivem indistintamente nos dois lados da fronteira Peru-Bolívia. Não internacionalizaram a territorialidade dos estados das vizinhanças. Estão ligados às suas tradições ancestrais de uso do Rio Madre de Dios, até a sua foz no Beni.

Os grupos indígenas na fronteira Peru-Bolívia poderão sofrer interferências com a estrada Brasil-Peru, na alternativa mais provável, acompanhando a fronteira boliviana a noroeste, impacto agravado em todo o norte boliviano, pela expansão das BR-429 e 425, comprometendo os rios-limites entre os dois países, Guaporé e Mamoré, anteriormente descritas:

- Yaminawa, grupo lingüístico Pano, na margem boliviana do Rio Acre;

- Ese’eja, grupo lingüístico Takana, em ambas as margens do Rio Madre de Dios;

- Tacana, grupo lingüístico Takana, no médio curso do Rio Beni;

- Quechua, grupo lingüístico Quechua, nas nascentes do Rio Tambopata; 
- Aymara, grupo lingüístico Aymara, em torno do Lago Titicaca (Fonte: Mapa Etnolinguístico da Bolívia - Instituto Nacional de Antropologia - La Paz).

\section{Alternativa de traçados, cidades, floresta, altiplano, litoral}

É verdadeira a afirmação de que a saída por Assis Brasil-Inapari-Puerto Illo é menos impactante sobre o ambiente e as comunidades indígenas, que a alternativa inicialmente proposta pelo governo do Acre, atravesssando todo o noroeste deste Estado, e um trecho maior da Amazônia peruana, por Pucallpa até Callao. Esta segunda alternativa, por Cruzeiro do Sul, comprometeria todo o Estado do Acre e é ainda mais desastrosa para o sul do Estado brasileiro do Amazonas. É a alternativa oficial brasileira desde o pós-guerra, e é a pior. Tal fato, no entanto, não muda nada relativamente à necessidade de se aprofundar a análise sobre as questóes do transporte intermodal e, sobretudo, relativamente às medidas sócio-ambientais, anteriores ao início de qualquer obra, condicionando seu cronograma.

Há diferentes alternativas de traçado também no interior do Peru, nenhuma delas sendo considerada adequadamente sob o ângulo das questóes sócio-ambientais. $\mathrm{Na}$ alternativa de poligonação para Cuzco, por exemplo, há numerosas questóes subestimadas. Há duas grandes empreiteiras brasileiras interessadas nessas obras: a Mendes Jr., melhor relacionada no Acre na altura de 1990, onde realizava as obras da BR-364, e a Odebrecht, que tem realizado vários trabalhos no Peru. Numa grande obra como essa, de qualquer forma, várias outras construtoras seriam envolvidas.

\section{Contradições na regionalização peruana}

Tanto Cuzco, quanto Puno, desputavam, na época, a estrada, ou seja, que seu traçado atravessace estas regióes. O Peru vivia o processo de regionalização, e Madre de Dios está ligado à região Inca, com Cuzco como capital. Há, apesar disso, um grande ressentimento de Madre de Dios contra Cuzco, que, no fundo, sempre intermediou a relação Lima-Madre de Dios. Puno também pretendia que Madre de Dios ficasse em sua região, considerando até que, com a estrada asfaltada, as relaçōes entre estes dois departamentos 
seriam prioritárias.

Madre de Dios pode fazer um plebiscito, tentando autonomizar-se de Cuzco. A legislação prevê ainda mais uma regiâo. No entanto, Lima também estaria interessada em transformar-se em uma região independente, anulando, neste caso, as pretensóes de Madre de Dios, por contar com maior força política. A média das opinióes na regiāo é pela autonomia de Madre de Dios. Uma outra região da Amazônia peruana conseguiu sua autonomia, o que aumentou os desejos de Madre de Dios.

Os ressentimentos contra Cuzco são importantes, os contra Lima são bastante pesados e definitivos. Assistiu-se, no final de fevereiro de 1990, em Madre de Dios, aos dois dias de greve geral de todo o departamento, contra a administração central.

A Fenamad, segundo uma resolução de seu VI Congresso, considera importante que tenha sido reconhecida como a organização representativa das comunidades nativas da região, não apenas de Madre de Dios, mas de Kcoshipata, Paucartambo e Cuzco. Deverá participar da Assembléia Regional com dois representantes, dentre os náo-eleitos por voto direto, para representarem associaçóes profissionais e da sociedade civil. Sua presença está prevista na Lei de Criação da Região e na Lei de Eleições Regionais. Podese esperar que os indígenas de floresta, minoritários, sejam melhor ouvidos, o que não é seguro, sendo dois entre dezenas de representantes da absoluta maioria Quechua. A Fenamad quer que Manu, Kcoshipata, Paucartambo e Cuzco sejam uma sub-regiáo, dentro da região Inca, pelo menos.

Protestam, porque os indígenas da selva de La Convención, de Cuzco, não conseguiram representação particularizada na Assembléia Regional Inca, em particular os Machiguenga e Piro, representados pela Feconay, Ceconama e Comaru. Reclamam ainda, em 90, uma melhor representação popular de Madre de Dios, em particular da Federação Agrária e da Federação de Assentamentos Humanos.

A descentralização representativa e administrativa permite criar diálogo mais direto com as autoridades, mas envolve interesses locais expressos com mais força. Ainda não está claro, portanto, como serão representadas no governo regional as questóes indígena e ambiental. Esse tema é chave no planejamento e implementação de um programa ambiental e social, 
destinado às comunidades indígenas, aos seringueiros e castanheiros.

Pelo menos parte da opiniâo em Madre de Dios insiste na autonomia. Em um artigo publicado pela revista Sur, do Centro Bartolomé de Las Casas de Cuzco, o antropólogo Thomas Moore lembra que "a Frente de Defesa dos Interesses de Madre de Dios, durante a maior parte da presente década, vem exigindo cada vez maior autonomia, e o fim do colonialismo interno". Considera que não há áreas contínuas histórica, econômica, administrativa e culturalmente integradas entre Madre de Dios e Cuzco, ou Puno, e menos ainda unidade geográfica, como orienta a lei para constituir uma região, uma vez que Madre de Dios e amazonica e Cuzco e andina: "hoje, ao final de 1989, mantém um caráter extrativo-mercantil de colonialismo interno, com Madre de Dios na periferia, dominada pelos donos de capitais que se acumulam em Cuzco, Arequipa e Lima" (1/1990).

O presidente da citada Frente de Defesa afirmou na altura de 90, em entrevista, que, se a estrada for feita, deve-se criar uma regiấo em Madre de Dios. Desconfiava de que a região Inca signifique progresso para Madre de Dios. Argumenta que sempre se pretendeu um governo regional autônomo, mas reconhece que não chegaram ainda a elaborar um projeto de desenvolvimento claro e definido (SUR,7/1989, p. 11).

\section{Estrada da Seca, Estrada para todas as estações}

Argumenta-se que asfaltar uma estrada já existente seria menos desastroso que abrir uma estrada na floresta virgem, como foi o caso da Transamazônica. Essa afirmativa é apenas relativamente correta. A BR-364, por exemplo, é o asfaltamento com correçôes de traçado da antiga BR-29, ou seja, também já existia, e nem por isso o impacto foi menor, como é conhecido.

Havia grande diferença, em termos sócio-ambientais, entre uma estrada para todas as estaçóes, de grande tráfego, perenizada pelo asfalto, e uma estrada apenas para a seca. A asfaltada cria em torno de si um grande impulso urbanizador, e uma aceleração da especulação, que a outra não chega a alcançar.

Ainda faltavam cerca de 30 a 60 quilômetros para tornar possível a estrada proposta por San Gaban, ou seja, a estrada existente é apenas parte da que se construirá. Há que constituiria em médio prazo também o impacto de 
poligonaçóes inevitáveis, como a do trecho alternativo Puerto Maldonado - Cuzco, no início de 90 intrafegável em boa parte do ano. Nas chuvas não se conseguia utilizar a estrada de Puerto Maldonado até o Brasil, sendo úteis apenas os 100 primeiros quilômetros, ou seja, a estrada asfaltada facilitaria no futuro uma ocupação mais ampla e efetiva.

Estima-se no Acre em 10 quilômetros, e em Madre de Dios em 2 a 3 quilômetros, a ocupação atual à beira da estrada. Não cabe dúvida de que o asfaltamento criará especulação fundiária e desmatamentos bastante mais amplos. A estrada, em seu ritmo de construção dos anos 90, avançava 4 quilômetros ao ano, com os poucos recursos do Estado peruano, ou seja, serão recursos internacionais, a débito externo, e a participação do Brasil, que viabilizarão sua construção a curto prazo, e que o fazem atualmente a partir dos interesses de exportação de soja e outros grãos, agora para a China.

Não se mantém o trecho Quince Mil - Inampari nas chuvas, uma vez que não há drenagem adequada, é mal conservado e necessitava então de obras de afirmação e pontes. O problema das estradas secundárias está bem representado pela situação em Shintuya, onde há um comércio no meio da aldeia indígena e um porto, parecendo mais uma feira ou mercado, iniciando uma nova cidade com alcoolismo e doenças, que uma comunidade indígena cujo habitat deve ser respeitado em sua integridade. Os ramais devem evitar áreas comunitárias ou de preservação.

O estudo prévio do impacto da passagem de estradas por comunidades ainda não estava resolvido. O problema já era desafiante na altura dos anos 90 no caso de Shintuya. Não se pode discutir em separado o eixo viário principal, sem sua malha irregular. Inclusive porque já teriam conseguido, da Cordemad e Corporación Cuzco, "cujos funcionários, identificados com a região Inca, se comprometeram a apoiar com máquinas pesadas a manutenção da estrada, onde se retira madeira e também alimentos existentes na zona do Manu" (El Sol, Cuzco, 5/3/1990). No mesmo artigo, informa-se que foi pedido ao presidente da República a declaração do estado de emergência para a estrada Cuzco - Shintuya. Todos os ramais devem ser previstos e compatibilizados com áreas de preservação, inclusive as indígenas ou extrativistas. 


\section{Floresta, altiplano e litoral}

Há três estudos de impacto que se faziam necessários desde os anos 90 no conjunto do traçado, qualquer que fosse a alternativa escolhida. Até o momento, trabalhou-se mais o caso das regióes de florestas da Amazônia peruana, tal como sugerido pela pressão da mídia e da opiniáo pública internacional mais bem informada, enfim, porque está na moda. A regiáo de Madre de Dios chegou a contar com um projeto de desenvolvimento integrado, bastante precário e perigoso, elaborado no quadro da comissão mista bilateral, da qual participei como consultor. Mas não se poderá ignorar o conjunto.

É impossível hoje que os outros trechos de qualquer traçado possam ser desconsiderados sob o ponto de vista sócio-ambiental. O Peru tem grande e rica diversidade em todos os sentidos. Atravessá-lo de ponta a ponta significa passar, vindo do Brasil, por floresta, serra e litoral. A diversidade das espécies serranas é táo importante quanto as de floresta. No altiplano, por exemplo, encontra-se um dos maiores centros mundiais de camelídios. Trata-se de ecossistemas igualmente frágeis e de decisiva importância para as populaçóes que ali vivem, também há milênios, de grande e complexa diversidade étnica. Há graves problemas de erosão, de defesa da vegetação nas encostas, dentre outros.

Um dos entrevistados, a título de exemplo, lembrou a llama, vicunha, alpaca, guzana, etc. Constituem inclusive recursos alimentares e econômicos de importância. A pele da vicunha pode alcançar 500 dólares a libra. Há ainda grande diversidade de ovinos. A alpaca, importante em Puno, está sendo criada con-correncialmente na Nova Zelândia, onde já havia em 90 um rebanho de 15 mil espécimes. Em Juliaca, centro de médias indústrias, que chegou a conhecer um relativo desenvolvimento econômico, vivia-se já em 90 graves problemas de mercado.

Nessas regióes também se colocam os difíceis problemas de valorização fundiária nas proximidades de uma estrada de grande tráfego. Há que se prever o impacto de sua passagem sobre comunidades e etnias, que poderão desestruturar-se gravemente, tornando a engrossar a marginalização urbana, e a isto não será possível chamar-se de "desenvolvimento". Também no caso dos outros pontos do traçado, a prioridade deve ser dada às populaçôes que 
ali estão, sobretudo às camponesas. Uma obra pode provocar numerosos reassentamentos, que terão de ser conhecidos a priori, e medidas de planejamento indicadas e iniciadas também anteriormente ao início da obra. Corre-se o risco de atravessar comunidades estabilizadas, e que alcançaram adequada qualidade de vida. Dissemina-se a ilusão que, nas florestas, as terras seriam férteis, o que não é verdade para a maior parte do espaço amazônico.

$\mathrm{O}$ esforço deve ser posto, inicialmente, para responder às dificuldades de radicação das populações, onde estão. Uma vez movidas por equívoco de política pública, tenderão a engrossar as cidades explosivamente, como já ocorre em Puerto Maldonado e Juliaca. Um homem na cidade custa enormemente mais que um na agricultura, sendo o último indispensável ao outro, e o inverso nem sempre é verdadeiro.

O litoral é um caso também até agora sem merecer a atenção adequada. A criação de um grande porto de exportação e importação, como se planeja para Puerto Illo, um dos maiores da costa latino-americana do Pacífico, não se fará sem grande urbanização e graves conseqüências para os ecossistemas costeiros. O porto, por exemplo, merece uma previsão de impacto particularizada.

Vale lembrar também as poligonaçóes, ramais e malhas viárias dos outros trechos do possível traçado, que devem ser profundamente estudados. Em particular a poligonação por Cuzco, que, embora precariamente existente, terá impacto previsível sobre populaçóes e ambientes em todo o seu traçado.

\section{Arqueologia e movimentos nacionais}

Eis outra questão determinante hoje em grandes obras de impacto. Há pouca reflexão sobre o tema em relação às estradas. Por exemplo, se houver poligonação asfaltada em direção a Cuzco, aproveitando a estrada atual, quais seriam as interferências com os grandes monumentos nacionais peruanos de importância mundial? Qual sua importância em Madre de Dios? Alguns dos ramais, ou o eixo da estrada, passarão sobre eles ou nas proximidades? Há estudos ou mapas? 


\section{Lago Titicaca}

Eis outro problema delicado, pois prevê-se a passagem da estrada, ampliando o tráfego em cerca de 400 caminhôes diários, segundo estimativas no inicio de 90, sobre a cidade de Puno, estimulando o turismo, acelerando a urbanização, e outras conseqüências. Qual é a especificidade do ecossistema do lago? Qual a relação do lago com a cidade, em termos de abastecimento e saneamento básico? Quais as medidas de proteção adequadas? Puno tem um plano sócio-ambiental e de urbanização? Há um povo indígena que habita o lago, transformado em objeto pelo turismo. Que medidas foram tomadas? O lago tem uma grande biodiversidade, como rãs gigantes únicas. Quais as conseqüências? Há petróleo no lago? Enfim, uma estrada exige prévias medidas e alternativas, como desviar-se de Puno.

\section{Narcotráfico}

Há zonas de plantação de coca em Cuzco e em Puno, e referências nas nascentes do Manu, nas vertentes orientais. Essa questão merece medidas preventivas, antes de uma obra do porte da estrada do Pacífico, e um prévio tratamento particularizado.

\section{Estradas, criadoras de cidades e de grandes obras}

Os grandes eixos viários da Amazônia transformaram- se, sem exceção, em criadores de urbanização precária e sem planejamento; mesmo quando pretendiam promover desenvolvimento rural, resultaram em efeito perverso. Cidades onde os rios transformam-se em esgotos, sem saneamento básico, com problemas graves de energia, de urbanização, enfim, uma péssima qualidade de vida.

\section{Puerto Maldonado}

É um bom exemplo. É a capital do Departamento de Madre de Dios. Simulacro de média cidade, sujeita a inundaçóes e falta de água, cidade de garimpo, com urbanização inadequada e espontânea. Essa explosão já é resultado da abertura, em 1965, da estrada Urcos-Quincemil-Puerto Maldonado, que não funciona em todas as estaçóes do ano, mas foi suficiente 
para criar graves imprevistos. Sofre de falta crônica de manutenção da própria estrada; falta de telefone: água potável; eletricidade; transporte aéreo desorganizado e irregular etc.

Estimavam-se 15 mil habitantes em 1984, quando se abriu a estrada em direção ao Acre. Hoje a população poderia estar acima de 25 mil, mas a flutuante, na seca, poderia chegar ao dobro deste número em torno do garimpo.

\section{Potencial hidroelétrico de San Gaban}

Eis outro indispensável estudo de impacto, considerado inofensivo no Peru, mas que cortaria um formador do Amazonas, dentre outras conseqüências a serem seriamente avaliadas. Tem estreita ligação com a estrada do Pacífico.

\section{Mineração}

Urânio em Puno, petróleo em Madre de Dios, garimpos, gás, todas estas reservas minerais devem ser avaliadas, plotadas em mapa, e consideradas suas conseqüências e regras próprias, sobretudo quando atingem áreas indígenas, extrativistas, ou áreas de preservação, pois serão impulsionadas com a estrada.

\section{Migração, conflitos interétnicos, garimpos: a frente colonizadora em Madre de Dios}

A migração de Puno, Cuzco, Arequipa e Tacna, já em curso, vem sendo grandemente ampliada em direção a Madre de Dios, com a abertura de um eixo viário central, com ramais importantes e poligonaçóes. Subestimam-se os conflitos de natureza cultural ou étnica que possam daí resultar. Hoje, com os poucos núcleos de colonização já assentados, a situação já não é cômoda.

Não é admissível tampouco o argumento de que a migração já está em curso, e que os projetos tenderiam a ordená-la. Simplesmente pela razão de que a atual migração dá-se em direção ao garimpo, e não à agricultura, inclusive de brasileiros e bolivianos. Os migrantes garimpeiros são com mais freqüência recrutados entre populaçóes urbanizadas, já descaracterizadas 
sob o ponto de vista de sua cultura. Dificilmente seriam aproveitados em assentamentos rurais permanentes. Quanto aos migrantes agrícolas vindos de Puno ou Cuzco, basta analisar o fracasso das tentativas anteriores de colonização em Madre de Dios, para se notar que não é possível repetir tais experiências, sem medidas corretivas de amplo alcance.

\section{Pelo Peru, para o Oriente: a Estrada do Pacífico - primazia e eficácia política do lobby da soja}

Dentre as obras de infra-estrutura, uma das mais estimuladas pelo lobby da soja, a que se destaca, é a chamada Estrada do Pacífico. Muito antes que a soja e outros grãos tivessem alcançado tal repercussão, como a ponta de lança da produção do agro-negócio de exportação, tal estrada vinha sendo planejada desde o governo militar nas décadas de 80 e 90, no quadro do PIN (Plano de Integração Nacional), inicialmente muito mais como uma estratégia militar de ocupação da Amazônia "vazia", do que propriamente uma estratégia ligada a uma atividade econômica específica.

Antigo objetivo do lobby da soja, buscado há décadas, mas melhor definido no início da década de 90, foi o da construção desta saída para o Pacífico, por rodovia (LEONEL,1992). Apesar de pareceres críticos e alternativos, com relação à possibilidade de uso de ferrovias, e da possível integração da Bolívia no sistema, este grupo, reunindo os lobbies da soja e de grandes construtoras, manteve-se firme em obter o asfaltamento etapa por etapa, de Porto Velho a Rio Branco, e, na continuidade, a um custo de US\$ 80 milhóes, no Acre, de Rio Branco a Assis Brasil. Não cabe dúvida que é de interesse nacional que o Brasil tenha uma saída de exportação de soja e outros produtos para o Oriente, mas saltava aos olhos, em 1990, o desinteresse ambiental dos exportadores e construtores, o seu desprezo pelo impacto sobre populaçóes tradicionais e a biodiversidade.

Chegou-se assim à fronteira com o Peru, sendo que o país vizinho iria encarregar-se da continuidade, até Puerto Illo; frente às dificuldades de negociar o financiamento multilateral do projeto binacional, as despesas voltaram ao inesgotável caixa brasileiro (LEONEL, 1992). Finalmente o governo brasileiro investiria mais cerca de US $\$ 450$ milhóes, no trecho peruano, dada á força do lobby, atuando com as empreiteiras Odebrecht e 
Andrade Gutierrez, sendo outra metade prevista a ser gasta pelo governo peruano e pela CAF - Corporación Andina de Fomento.

Desde os primeiros planos de construção encontravam-se já atuando na regiāo, na construção da BR-364, Cuiabá-Porto-Velho-Rio Branco, e em Hidrelétricas, como a de Samuel, as construtoras Norberto Odebrecht e Andrade Gutierrez, que estiveram sempre presentes a cada passo das negociaçóes e dos planos de engenharia. (FSP, 24/ 06/ 05: B8). Durante o período de espera das negociaçóes as duas empresas dedicaram-se a obras de saneamento no Peru. Obviamente terminaram por ganhar a concorrência para a construção do trecho em curso que liga Assis Brasil, na fronteira do Acre com Puerto Illo, no Peru, a saída estratégica da produção de grãos ao Oriente, China e Japão em particular, aumentando em $60 \%$ a produção. Para concretizar o Corredor Inter-Oceânico Sul-Peru-Brasil, rodovia de 1.200 quilômetros no trecho peruano (LEONEL, 1992).

O total da obra é estimado em US\$ 810 milhóes, sendo que o governo brasileiro se dispôs a financiar US\$ 420 milhões via Programa de Financiamento às Exportaçóes (Proex), ou seja, soja. O governo peruano e a Corporación Andina de Fomento (CAF) completaram os investimentos. O Corredor faz parte de um dos 10 eixos de integração latino-americana definidos pelo IIRSA (Iniciativa de Infra-estrutura Regional Sul-Americana), entidade criada na cúpula de Brasília, em 2000, para coordenar as açóes para a integração sul-americana.

\section{A primazia e a eficácia política do lobby da soja}

O governador do Mato Grosso, Blairo Maggi, o "rei da soja”, foi reeleito com $65,39 \%$ dos votos do estado, detentor, portanto, de uma força política imbatível, com ramificaçóes nos estados vizinhos. Reunindo, entre outras, as grandes exportadoras de soja, na sua maioria estrangeiras, como a Cargill, Bunge, ADM, Born, Dreyfus, Mitsui e Sumimoto, e a brasileira Grupo André Maggi, empresa fundada por seu pai. A força político-eleitoral que reuniu no Mato Grosso é equivalente à que conquistou nos negócios de exportação, com força interna e externa. O lobby é política e tecnicamente organizado a partir da Fundação Rondonópolis (MT).

Seu partido original, de oposição, o PPS, não desejava seu acordo com 
Lula, nas eleiçóes de 2006. No período eleitoral, no entanto, foram numerosas as vantagens que o governador trocou com o candidato majoritário, Lula, a tal ponto, que se prevê hoje sua transferência a um partido da situação. Próximo às eleiçóes, Maggi calculou que o governo federal repassaria aos interesses da soja cerca de $\mathrm{R} \$ 3$ bilhóes, em troca de apoiar a continuidade de Lula. Já no dia 16/10/06, o governador anunciava o repasse de um bilhão de reais para a comercialização da soja (FSP,14/10/06:A6). Sua força política e de seu grupo vem da interpretaçáo que o enriquecimento dos seis ou sete grandes exportadores de soja termina por ser um ganho econômico a todos os eleitores do estado, o que não é uma conclusão segura.

O lobby da soja é um dos grupos de interesses melhor sucedidos do Brasil contemporâneo, dadas suas relaçóes nacionais e internacionais. $\mathrm{O}$ movimento político que realizou, capitaneando milhares de produtores em mais de sete estados, foi incomum. Fecharam estradas, capitais de estado e terminaram em Brasília. Foram incontáveis as obras de infra-estrutura, subsídios, moratórias de juros e dívidas, que foram aos poucos arrancando dos cofres públicos, até o acordo Lula-Maggi. Tome-se, por exemplo, a construção da Rodovia Cuiabá-Santarém, a qual inicialmente os produtores de soja chegaram a propor construir com seus próprios recursos, além de dezenas de outras estradas e hidrovias que se ligam ao complexo soja. Em 2004 o governo aprovou as parcerias público privadas PPPs, e já na altura as principais das obras citadas eram ligadas, a soja por exemplo, à construção do trecho Rio Branco- Assis Brasil, da Estrada do Pacífico, para a qual o governo financia agora o trecho que vai até ao porto em Puerto Illo no Peru, com US\$410 milhóes, o asfaltamento da estrada Porto Velho - Manaus e o sistema de hidrovias. Esses PPPs prevêem 22 projetos, 13 bilhóes de investimentos, 30\% governamentais. (FSP,23/12/04:B4). Mas na realidade, os investimentos terminam por sair do orçamento público.

O governo brasileiro há alguns anos vem cedendo ao grupo soja, embora represente interesses minoritários no setor agropecuário, prejudicando outros produtores, e o que é mais grave, a agricultura familiar. Não há dúvida que o apoio ao lobby soja, advém do estímulo que este setor conquista, desproporcionalmente, devido à visibilidade de crescimento na economia nacional de exportação, e à competente articulação e propaganda de que 
é capaz, além das áreas de influência, troca de favores e interesses e outras estratégias típicas de grupos de pressão. No primeiro semestre de 2006, o governo fez seu terceiro empréstimo, em menos de três meses, eleição em curso e Maggi eleitoralmente forte, o governo libera custeio para a nova safra de R \$ 50 milhôes (FSP, 25/5/06 B12). Novas áreas ocupadas em prejuízo da agricultura familiar, dejetos aos rios, agrotóxicos, compactação dos solos, contra pouquíssima mão de obra contratada.

O lobby brasileiro, detentor de tecnologias, máquinas e sementes, terminou por avançar sobre a Argentina, Paraguai e Bolívia. Os brasileiros que se encontram na Bolívia temendo a reforma agrária de Evo Morales, e participando das manifestaçóes de seus opositores, em 9 estados. Um jornalista brasileiro, Washington Novaes, comenta que se fala no déficit da Previdência, mas que se oferece em um só pacote para socorrer o agronegócio, 16 milhóes de reais, isto porque o lobby promove manifestações agressivas exigindo facilidades do governo em 2006.

O lobby de Maggi e parceiros acessam com facilidade grupos financeiros multilaterais. Pediram US\$ 30 milhóes emprestados ao Banco Mundial, pela IFC International Finance Corporation, setor de empréstimo privado (FSP, 22/9/04 - a12). Pretendia o grupo André Maggi para plantar $250 \mathrm{mil}$ toneladas de soja perto do Rio Xingu e do parque indígena, regiōes frágeis e vulneráveis. O Fórum das Ongs brasileiras pediu ao braço do banco mundial que financia iniciativa privada, que considerasse o pedido como de alto risco ambiental. O grupo Maggi argumentou que não iria usar áreas de florestas, mas as desmatadas.

Segunda tentativa (FSP/30/12/04), um grupo de São Paulo com atividades no Pará (BERTIN) pede ao IFC/BM US\$ 100 milhóes, para regiôes com risco de desmatamento para pecuária, ambos os empréstimos foram considerados com risco ambiental B e negados, o que mostra que muitas das iniciativas do lobby podem criar reaçóes efetivas das ONGs.

Os jornais brasileiros mostram como o lobby não tem pudor em seus pedidos de favores aos orçamentos públicos (OESP -27-4-06 B10), como neste caso: informa o governador do Mato Grosso que pretende que o setor soja esteja endividado, não se sabendo se são obrigados a pagar ou não, dívidas privadas, por exemplo. O governador termina por dizer que o setor 
iria perder 30\% da produção, 2 milhóes de toneladas. Resultado, o lobby termina em campanha para negociar 7,7 bilhóes de reais, em parte do setor privado. Conseqüência: a dívida não se confirmou, parecendo um blefe de antecipação insegura: antes de perder, tentar, o governo nos ajuda.

O motivo da crise de 2005 e 2006 no caso da soja é uma crise cambial, favorecendo, sobretudo, os concorrentes norte-americanos. Riscos de qualquer negócio. Após a pressão das manifestações o governo libera $\mathrm{R} \$ 75,5$ bilhões para a agricultura. Ano eleitoral: nunca se viu um lobby retirar tanto subsídio, redução de juros, investimentos.

Dos 75 bilhões ao agrobussines, só 10 bilhões são para agricultura familiar! Mais grave: os pequenos estarão daqui para a frente, dependentes da transgenia, seguindo os lobbies. Com as patentes, nunca tão dependentes como antes, uma vez que o transgênico é patenteado como propriedade intelectual, estamos diante de uma "contaminação genética", com risco de expansão nas lavouras vizinhas, o que pode impedir a soja convencional, tornando os pequenos dependentes dos insumos das grandes empresas. $\mathrm{O}$ resultado é a dependência do capital das grandes, monopolizado, agravado pela concorrência dos pequenos, terminando por excluir grande parte deles.

\section{O lobby da soja toma a dianteira no biodiesel}

No curto período da pequena crise da soja, nos anos 2005/2006, pareceu a seus líderes que uma grande alternativa seria o Biodiesel de soja, até porque esperavam, como sempre, privilégios governamentais. Em 20/11/06 o presidente do Brasil, Lula, e o "Rei da Soja”, e governador do Mato Grosso, Blairo Maggi (FSP,19/11/06-B1), comemoraram a entrada da soja no Biodiesel, assim como a mamona. A impressão é que a mamona e a agricultura familiar apareceram para evitar que se diga que é um negócio reservado aos reis da agroindústria, e que aos pequenos se deixaria um espaço, mesmo que rarefeito e desproporcionalmente menor.

A primeira ação do lobby é procurar forçar o governo a aumentar a demanda do produto, com a expectativa de que o governo venha a ceder. Pressionam para que o biodiesel chegue à obrigatoriedade de 5\% em 2010. Hoje é correspondente a $2 \%$ do combustível usado. Quem são os donos do negócio em escala? Quem poderá ditar regras? 
Novamente na frente o lobby soja: a ADM norte-americana vai construir uma fábrica em Rondonópolis (MT), sede do cartel, para 180 milhóes de litros. Empresas brasileiras entrariam no mercado, Granol, Caramuru, Oleoplan, chegariam a 400 milhóes de litros. O BNDES vem bancando, o que não é inusitado. E a Petrobrás terá participação no mercado. Falase em $30 \%$ do negócio para a agricultura familiar, mas nada ainda que o confirme.

Para explicar o papel da agricultura familiar, esta se somaria aos restos da soja de exportação para, fornecer pequena parte destas quantidades de biodiesel. Silvio Crestana, diretor da Embrapa, é mais prudente. Não se deve começar a construir a casa pelo telhado, diz, há problemas ambientais de certificação, que podem deixar o Brasil fora da civilização da biomassa, adverte. A soja produz só $20 \%$ de óleo, $80 \%$ sobram. E há alternativas no nordeste: cana , mamão, mamona, pinhão-manso. Soja é para alimentação animal. Levaríamos 30 anos para atender a demanda, recuperando 50 milhóes de hectares de pastagens pouco produtivas, precisaríamos de 40 milhóes de hectares extras. Para obter estes resultados custaria investir R $\$ 80$ bilhóes de reais. Por isso é mais barato derrubar florestas.

Todavia fora da Amazônia, em Floriano, no semi-árido do Piauí, em 2005, abriu-se uma unidade modelo para Mamona e soja, a partir da fazenda Santa Clara e Recanto do Buriti, envolvendo agricultura familiar. Um ano depois, teve-se queda na produção, denúncias de abuso, trabalho escravo e infantil, a procuradoria do trabalho abriu inquéritos. Enfim um bom exemplo do papel reservado à agricultura familiar (FSP/ 19/ 11/ 06 - B7). Pretendia-se proteger os pobres, hoje se produz $97,2 \%$ de soja, $2,1 \%$ da mamona e $0,7 \%$ de algodão. A soja está sempre com mais de $70 \%$, a mamona perdeu o selo social. A empresa fixa o preço da mamona, e os pequenos produtores ficam descontentes. Os produtores de soja são os maiores e os que mais lucram.

A agricultura familiar perde com o novo diesel da soja, diz coordenadora de um grupo de estudos da UNB, a socióloga Laura Duarte: não adianta pretender resolver o problema energético com exclusão social e impactos ambientais. Quem vencerá será o agronegócio, trazendo monocultura, exclusão social e danos ao ambiente, mesmo com a tecnologia da Petrobras H-Bio, a soja vai ganhar também da mamona, palma, girassol e algodão. Não 
deve gerar emprego e as multinacionais concentrarão o esmagamento (FSP23- 05- 06 B11). A soja é o grão mais disponível e com melhores preços, e o mais barato, comparado ao amendoim, por exemplo. A soja sai $\mathrm{R} \$ 1,25$, o amendoim $\mathrm{R} \$ 1,60$.

O poder público, o próprio presidente Luiz Inácio Lula da Silva, deu o destaque a um ato simbólico a favor do grande capital do agronegócio e da soja como principal matriz energética do biodiesel. No Mato Grosso, hospedou-se na fazenda do governador local, Blairo Maggi (ex-PPS), um dos chamados "reis da soja" do Brasil, de onde seguiu para Barra dos Bugres (150 km a oeste de Cuiabá), onde participou da inauguração de uma usina de biodiesel cuja produção inicial será apenas a partir da soja.

Já na campanha eleitoral de 2006, Lula anunciava o biodiesel como um possível substituto do petróleo; e para a fixação dos trabalhadores no campo, ficando a soja para o agronegócio e a mamona para os pequenos agricultores. As esmagadoras de grãos começaram a instalar as unidades de produção do combustível, para pressionar o governo, exigindo o aumento da demanda pelo produto biodiesel soja. A obrigatoriedade do uso está prevista para começar em 2008, mas com exigência rigorosa em 2010, com 2\% de mistura do combustível vegetal ao diesel de petróleo. O governo cede ao lobby admitindo a possibilidade de antecipar a segunda parte do programa, inicialmente prevista para 2013, na qual a mistura obrigatória de biodiesel aumenta para 5\%, desta forma a demanda cresce para até 2,7 bilhões de litros por ano, superior ao mercado atual, com $2 \%$, que é de 1 bilhão de litros por ano.

A contratação de projetos pelo BNDES (outubro de 2006), dois da agroindústria da soja, com Granol e Caramuru, teve um investimento de R \$ 464 milhôes. Os empresários da soja esperam que, inicialmente, essa cultura responda por $90 \%$ do fornecimento de matéria-prima para a produção de biodiesel. Prevêem que em médio prazo, terão entre $75 \%$ a $80 \%$ do mercado, dos quais $60 \%$ para a soja. O grupo Maggi fechou contrato para fornecimento de óleo de soja para a Brasil Ecodiesel, empresa pioneira no programa, apoiada pelo governo e que, supostamente, estaria produzindo biodiesel a partir da mamona, produzida por cooperativas no Piauí. $\mathrm{Na}$ verdade, de acordo com relatório apresentado à CVM (Comissão de Valores Mobiliários) 
e ao mercado em geral, a Brasil Ecodiesel já informa que sua matéria-prima principal é o óleo de soja $(97,2 \%$ dos custos de produção, contra $2,1 \%$ da mamona e $0,7 \%$ do algodão). Além da indústria da soja, a Petrobras deve ter participação importante no mercado. A estatal está iniciando a construção de três usinas, analisa mais 15 projetos e tem como meta produzir 855 milhóes de litros de biodiesel por ano até 2011, mas as indústrias da soja estão abrindo fábricas na frente da Petrobrás. (FSP 23/11/2006).

O programa do governo é montado com incentivos fiscais para estimular a participação da agricultura familiar. Mas a agroindústria da soja já tem uma estratégia para prescindir desse incentivo: montar fábricas em locais distantes das refinarias da Petrobras, para que o preço do combustível vegetal fique mais competitivo em relação ao diesel de petróleo. Segundo expectativa do próprio governo, a agricultura familiar deve ficar com cerca de $30 \%$ do negócio de fornecimento de matéria-prima para o biodiesel, enquanto o agronegócio ficará com $70 \%$ restantes.

Interessante a observação feita por Lester Brown, em seu livro Plan B 2.0: Rescuing a Planet Under Stress and a Civilization in Trouble (2006). Lester Brown é um dos mais importantes autores sobre a questão ambiental, exeditor da série State of The World, do World Watch Institute, hoje no Earth Policy Institute.

"Ao importar Soja do Brasil a China está importando água", é a observação de Lester, argumentando que uma tonelada de soja exportada representa 1000 toneladas de água. A China que deu origem a soja, e detém centenas de espécies, mas carece de água, importa soja dos países que têm água. A agricultura consome 69\% da água doce. Desperdiça água, erosão dos solos, desmatamento do cerrado e da Amazônia e assoreamento dos Rios, em troca de bens industrializados.

Os exportadores da soja dizem que agora o agronegócio vai exportar produtos beneficiados como combustíveis, a partir do biodiesel de soja, mas também álcool de cana, mamona e dendê. Assim a troca com a China é a de bens industrializados, em contrapartida o Brasil, com muita água e biocombustíveis. Quem sai ganhando?

A soja brasileira enfrentou-se com a China que descobriu fungicidas na soja brasileira. A China barrou carregamentos de soja com sementes tratadas a 
carboxin, também vindas da Argentina. Com isto a China endureceu também as regras sanitárias para o óleo de soja. A China é a maior importadora de soja do Brasil, 6 milhóes de toneladas. Alguns interpretam que a China possa colocar dificuldades para abaixar o preço. Mesmo no ano da crise de 2005 o Brasil manteve a liderança da exportação à China, apesar da queda do dólar.

O Greenpeace, Abiove, Trades, acertaram uma moratória da soja que proviesse do desmatamento (FSP -06-12 06 - A3). O articulista Marcio Santilli comentou, no entanto, que o acordo não leva obrigatoriamente a uma melhoria da qualidade sócio ambiental da produção. Há um tema transgênico mal resolvido, lembra. Além dos graves problemas fundiários, os relativos ao respeito à legislação trabalhista, trabalho infantil, trabalho escravo, e, sobretudo, a ameaça à supressão da cobertura vegetal nativa. E adverte também sobre o risco de considerar toda soja brasileira como comprometida com o desmatamento e prejudicar o produtor limpo da região sul, por exemplo.

O desmatamento tem levado a novas exigências internacionais: a Holanda e a União Européia querem certificação de origem, para a criação de um padrão de combustível renovável, querem ausência de poluição na água da usina, proibição de queimadas, com preservação da floresta e do socoambiental, nem trabalho escravo e nem de menores.

Os exportadores brasileiros terão que se precaver, quanto às certificaçóes exigidas pelos importadores, até porque o agronegócio chegou em 2005, considerado um ano de crise, com a soja exportando US\$10 bilhóes (FSP $070105-\mathrm{B} 3)$. 


\section{Referências Bibliográficas}

AB'SABER, Aziz N. zoneamento ecológico e econômico da Amazônia: questão de escala e método. Estudos Avançados, São Paulo, IEA/USP, v. 3, n. 5, 1989 .

- Problemas regionais de desmatamento em áreas interfluviais na Amazônia. Reunião Anual. São Paulo: SBPC, 1988 (Datilografado).

AMORIM, Celso. Discurso del Ministro de Relaciones Exteriores de Brasil, Embajador Celso Amorim, em el foro sobre la iniciativa de la cuenca del Pacífico latino-americano. Disponível em: http://www.embajadabrasil.org. pe/vercontent.php?idseccion. 13 Mayo. 2008.

ARRUDA, Rinaldo S. V. A luta por Japuira. Aconteceu. Povos indígenas do Brasil. São Paulo: CEDI, 1986.

BALVÍN, Doris; PATRÓN, Patrícia. Carretera interoceánica sur: consideraciones sobre su aprovechamiento sostenible. Lima: Amigos de la Tierra, Asociación Civil Labor, 2006.

BLIKSTAD, Karin; RODRIGUES, Paulo Henrique; VIEL, Ricardo. Caminho ao Pacífico paga tributo a incas. Folha de São Paulo, Caderno Mundo, 1 dez. 2007.

BROWN, Irving F.; BRILHANTE, Silvia H. C.; MENDOZA, Elsa; OLIVEIRA, Ivanir R. de. Estrada de Rio Branco, Acre, Brasil aos Portos do Pacífico: como maximizar os benefícios e minimizar os prejuízos para o desenvolvimento sustentável da Amazônia Sul-Ocidental. In: Encuentro Internacional de Integración Regional - Bolivia, Brasil y Peru. Lima: Editora CEPEI (Centro Peruano de Estudios Internacionales), 2002.

CARVALHO, Edgard de Assis. As alternativas dos vencidos. Rio de Janeiro: Paz e Terra, 1979.

CARVALHO, J. Porfírio F. de. Waimiri Atroari: a história que ainda não foi contada. Brasília: Ed. do Autor, 1982.

CEDI/PETI. Terras indígenas no Brasil. São Paulo: CEDI, 1990. 
COSTA, M. A. Relato de uma expedição de contato indigenista. Goiânia: IGPA/ UCG, 1980.

CRAIG, Neville B. Estrada de Ferro Madeira-Mamoré: história trágica de uma expedição. São Paulo: Nacional, 1947.

DAVIS, Shelton. Victims of miracle. Cambridge: Cambridge University Press, 1977.

FEARNSIDE, P. M.; FERREIRA, G. de L. A farsa das reservas. Ciência Hoje, Rio de Janeiro, SBPC, v. 3, n. 17, 1985.

FEARNSIDE, P. M.; LAURANCE, W. F. $O$ futuro da Amazônia: os impactos do Programa Avança Brasil. Ciência Hoje, Rio de Janeiro, v. 31, n. 182.

FIPE. Relatório da avaliação do componente indígena e ambiental do Polonoroeste. São Paulo: Coordenação, MINDLIN, Betty, 1983 a 1987.

FOLHA DE SÃO PAULO. Impacto ambiental de estrada preocupa: Rodovia que cruza Amazônia peruana deve atrair agricultores e pecuaristas. Folha de São Paulo, Caderno Mundo, 1 dez. 2007.

. García usa rodovia para obter crédito político, diz sociólogo. Folha de São Paulo, Caderno Mundo, 1 dez. 2007.

GOODLAND, R.; IRWIN, Howard. A selva amazônica: do inferno verde ao deserto vermelho? São Paulo: Itatiaia/Edusp, 1975.

GUIMARÁES, Paulo. Construção de usinas hidrelétricas em áreas da Amazônia legal. Brasília: CIMI, 1986 (Datilografado).

IANNI, Octávio. Ditadura e agricultura: o desenvolvimento do capitalismo na Amazônia, 1964-1978. São Paulo: Civilização Brasileira, 1979.

. Colonização e contra-reforma agrária na Amazônia. Petrópolis: Vozes, 1979.

JUNQUEIRA, Carmen; MINDLIN, Betty. El Parque Indigena Aripuanã y el Programa Polonoroeste. Copenhagen: IWGIA, 1987.

JUNQUEIRA, Carmen; PAIVA, Eunice. O Estado contra o indio. São Paulo: PUC, 1985. 
LEAL, Paulo Nunes. O outro braço da cruz. Porto Velho: Governo do Estado, 1984.

LEONEL, Mauro. Biossociodiversidade: preservação e mercado. In: RIBEIRO, Wagner Costa (Org.). Patrimônio Ambiental Brasileiro. São Paulo: Edusp, Imprensa Oficial do Estado de Sáo Paulo, 2003.

. Configuraçóes das Amazônias: políticas, mercados e biodiversidades. São Paulo: no prelo (IAMÁ), 2008.

. Carreteras, indios y ambiente en la Amazonia. Copenhagen, 1992.

- Colonos contra amazônidas no Polonoroeste: uma advertência às políticas públicas. In: LÉNA, P. A fronteira agrícola. Belém: MPGE, 1991.

. Environment, poverty and indians. Co-autoria JUNQUEIRA, C; MINDLIN, B. Haia: B. Novib, 1991.

. Estradas. In: LEONEL, Mauro. A morte social dos rios. São Paulo: Perspectiva/IAMÁ/FAPESP, 1998. p. 184-186.

. Estradas, índios e ambiente na Amazônia: do Brasil Central ao Oceano Pacífico. São Paulo em Perspectiva, v. 6, n. 1 e 2, p. 134-168, jan./jun. 1992.

- Estradas, índios e ambiente na Amazônia: do Brasil Central ao Oceano Pacífico. In: RECONDO, Gregório (Dirección y Compilación). Mercosur: una historia común para la integración. Tomo I. Buenos Aires y Asunción: Consejo Argentino para Las Relaciones Internacionales (CARI) y Multibanco S.A.E.C.A (coedición), 2000. p. 69-107.

Índios e ambiente: a eficácia da pressão externa sobre governos latinoamericanos. In: Entre la resignación y la esperanza. Asunción: CEDHU/ Tricontinental Ed., 1989.

. La de-demarcazione dei territori Uru Eu Wau Wau. Amazzonia, Milão, Vechio Faggio/L'Altra Voce Saggi, 1992.

- Obras públicas, estradas e hidrelétricas. In: LEONEL, Mauro. Etnodicéia Urueuauau. São Paulo: Publicações Europa-América, Edusp, FAPESP, IAMÁ, 1995. p. 156-162. 
. Roads, indians and the environment in the Amazon: from the Central Brazil to the Pacific. Copenhagen: IWGIA, 1992.

LÉVI-STRAUSS, C. Tristes trópicos. Lisboa: Ediçôes 70, 1981.

MARTINS, Edílson. Amazônia, a última fronteira. Rio de Janeiro: Codecri, 1981.

MINDLIN, Betty. Nós Paiter, os Suruí de Rondônia. Petrópolis: Vozes, 1985.

MINISTERIO DE AGRICULTURA. Directorio de comunidades nativas. Lima: Min. Agr., 1986.

MORAIS, F.; GONTIJO, Ricardo; CAMPOS, Roberto. Transamazônica. São Paulo: Brasiliense, 1970.

RIBEIRO, Berta. O indio na história do Brasil. São Paulo: Global, 1983.

RIBEIRO, Darcy. Os indios e a civilização. Petrópolis: Vozes, 1979.

RODRIGUES, Arion. Levantamento das linguas indígenas brasileiras. Campinas: Unicamp, 1984.

SEPLA-RO. Anais do Primeiro Seminário de Ecologia Humana de Rondônia. Porto Velho: SEPLAN, 1984. 